\title{
The Association between Corporate Governance and Corporate Disclosure: A Critical Review
}

\author{
Mohamed Omran (Corresponding author) \\ Department of Accounting \& MIS \\ College of Business Administration \\ Gulf University of Science \& Technology (GUST) \\ Mishref Campus, Kuwait \\ Tel: +965 $25307428 \quad$ E-mail: omran.ma@gust.edu.kw \\ Marwa Abdelrazik \\ El Mamoura Company for Construction \& Tourism Development \\ Alexandria, Egypt \\ Tel: 20-122-830-0263 E-mail: marwa_m_moh_mm@yahoo.com
}

Received: July 19, 2013 Accepted: July 28, $2013 \quad$ DOI: 10.5296/jpag.v3i3.4028

\begin{abstract}
This study provides a critical review of different techniques used in recent accounting literature to investigate the association between corporate governance and corporate disclosure. Therefore, the main purpose of this study is to help future researchers to identify examples and to select suitable practices or to develop their own ones. It also provides contest of current issues related to the relationship between corporate disclosure and corporate governance and identifies gaps in the current literature that future research may aim to cover. The study examines 34 articles published during the 2007-2013 period. The review of these articles concludes that most of these published studies examined the association between corporate disclosure and one or more of board of directors, ownership construction and audit firm. The current study suggests that researchers can also examine the association between internal audit quality as an internal governance and corporate disclosure. The study reveals that researchers used a disclosure index and content analysis to measure corporate disclosure. However, other techniques can be applied as management earning forecast and the number of analysts.
\end{abstract}

Keywords: Corporate governance, Corporate disclosure, Board of directors, Ownership construction, Firm, information asymmetry, Management earning forecast. 


\section{Introduction}

Corporate disclosure is a channel through which the existing and potential shareholders can obtain valuation information regarding the firm. It is also the connection between corporate insiders and capital market investors. Therefore, if there is new information; it cannot remain undisclosed as it should be disclosed either mandatory or voluntary (Al akra et al., 2010; Hassan, 2013). The content of disclosure reveals not only a firm's financial and operational situation, but also its managers' incentives and discretions to disclose relevant information. Moreover, it reflects the power managers can exert on disclosure decision making, and the distribution of this power among managers and shareholders that is integrally linked to the firm's corporate governance and as information is distributed through different channels to different receivers, information asymmetry arises among market participants (Khlif \& Souissi, 2010).

In conclusion, the effect of corporate disclosure as a connection between managers and shareholders involves the association of management power and shareholder variation. It characterizes the link between corporate governance and information asymmetry through the compound relationships between corporate governance and corporate disclosure, and corporate disclosure and information asymmetry (Yifang, 2009, pp.1-2). Various studies on the relationship between corporate governance and corporate disclosure have been done on various capital markets around the world (for example, see Wong, 2001; Haniffa \& Cooke, 2002; Eng \& Mark, 2003; Cheng \& Courtenay, 2006; Barako et al., 2006; Li \& Qi, 2008).

Garcia-Meca and Sanchez-Ballesta (2010) apply Meta analysis to a sample of 27 empirical studies to clarify the association of board independence and ownership concentration with corporate voluntary disclosure. They examine whether various in results are attributable to the difference in the corporate governance system, the investor protection right and the measurement of governance variables. They find that there is a positive association between board independence and corporate voluntary disclosure that only occurs in countries with higher investor protection right. Furthermore, Khlif and Souissi (2010) use a Meta analysis technique developed by Hunter et al. (1982) to a sample of 16 articles published during 1997-2006. They find a positive association between corporate voluntary disclosure and audit firm size.

This study aims to review the relationship between corporate governance and corporate disclosure to help future researchers to fill the gap in literature and to develop their alternative measures of corporate disclosure and new governance. So, the remaining of this paper is constructed as follows. Section 2 covers the critical literature review, followed by the summary, conclusion and suggestion in Section 3.

\section{A critical review}

\subsection{Studies in 2007}

Huafang et al. (2007) examine the impact of ownership structure and board composition on corporate voluntary disclosure of listed companies in china. They use an Ordinary Least-Squares Regression (OLS) to test the association among ownership structure, board composition and the level of corporate voluntary disclosure. Their results show that higher 
block holders ownership and foreign listing shares have an association with increased corporate voluntary disclosure; however managerial ownership and state ownership are not related to corporate voluntary disclosure. Finally, Huafang et al. (2007) find that an increase in independent directors, corporate disclosure and Chief Executive Officer (CEO) duality is associated with lower corporate voluntary disclosure.

Tsamenyi et al. (2007) use corporate disclosure scores to examine the corporate governance practices of Ghanaian listed companies gathered from 22 listed companies on the Ghana Stock Exchange. Their study finds that the level of corporate disclosure in Ghana is low. Furthermore, ownership structure, dispersion of shareholding, and firm size (measured as total assets and market capitalization) all have significant effect on corporate disclosure (Tsamenyi et al., 2007).

In addition, Barako (2007) examines factors associated with voluntary corporate disclosure of four type of information, general, strategic financial, forward looking, social and board information in annual reports of Kenya listed companies. Using OLS, he provides longitudinal examination of corporate voluntary disclosure practice from 1992 to 2001. The results show that corporate voluntary disclosure is influenced by ownership structure and governance attributes (Barako, 2007).

\subsection{Studies in 2008}

Kent and Stewart (2008) examine the association between corporate mandatory disclosure and corporate governance quality by using a number of sentences explaining how the transition to the Australian Equivalent of International Financial Reporting Standards (AIFRS) is being managed and an index of the number is changed to accounting policies discussed in the note to the account pertaining to the transition to AIFRS. They found that corporate disclosure quality is positively related to board size and audit firm size; on the other hand, there is no relation between board committee independence and corporate mandatory disclosure.

In China, Li and Qi (2008) use an entropy theory assessment method and they selected data from 100 listed companies in Shanghi and Shenzhen stock exchange, the results show that companies with high managerial ownership have high levels of corporate voluntary disclosure, the ownership concentration and by state owned stock control company; the big listed companies carry on the voluntary information disclosure positively. Chen et al. (2008) find that family owners on average prefer less voluntary disclosure.

Donnelly and Mulcahey (2008) examine the association between corporate governance and corporate disclosure by using a disclosure index based on Eng and Mark (2003); the results show that there is a positive relationship between non executive directors and the greater the level corporate voluntary disclosure. However, there is no relationship between managerial ownership, institutional investors and corporate governance.

\subsection{Studies in 2009}

Laidroo (2009) investigates the impact of ownership structure on public announcement disclosure in the context of three European emerging capital markets (Tallinn, Riga and 
Vilnius stock exchanges). Disclosure qualities was proxies with the disclosure score based on six disclosure quality attributes selected upon the basis of information theory and with quantitative disclosure measures, numbers of sentences and number of announcements disclosed, the study shows that there is a negative association with ownership concentration and foreign ownership and positive association with institutional ownership. In Malaysia, Akhtaruddin et al. (2009) investigate the extent of corporate governance and voluntary corporate disclosure in Malaysian listed companies. They find that there is a positive association between proportion of independent non executive directors and corporate voluntary disclosure. However, the extent of corporate voluntary disclosure is negatively related to family control and the ratio of audit committee members on the board is not related to corporate voluntary disclosure in corporate annual reports of Malaysian listed companies.

Bokpin and Isshaq (2009) examine the interaction between corporate disclosure and foreign share ownership on the Ghana stock exchange. Their study follows the trinary procedure of Aksu and Hosedag and use the standard \& poor's transparency and disclosure index, the results indicate a statically interaction between corporate disclosure and foreign share ownership. Apostolos and Nanopoulos (2009) use two disclosure indexes were built using as sample of published annual reports for 2004 of all the listed manufacturing and construction companies in the Athens Stock Exchange (ASE) to examine the relationship between corporate governance and corporate disclosure. The first index contains mandatory items according to Greek General Accepted Accounting Principles (GGAAP); and the second index contains items that are numbers of selected International Accounting Standards (IASs). The study uses a cross-section model, in which each type of disclosure index was regressed on proxy-related variables with corporate governance and voluntary disclosure in order to detect the existence of a statistically significant relationship. The major finding of Apostolos and Nanopoulos (2009) is that there is a significant extent of noncompliance in respect of IASs and the disclosures of Greek regulations. The key factors associated with the levels of compliance with IASs include the composition of the board of directors, profitability and the number of common shares. The public firms in the sample have shown that because of the political cost, the management is forced to disclose accounting data and support transparency.

\subsection{Studies in 2010}

Haron and Akhtaruddin (2010) examine the linkages between board ownership; audit committees' (ACs) effectiveness in terms of the proportion of independent non-executive directors (INED) and expert members on the AC and corporate voluntary disclosures. By using a sample of 124 public listed companies in Malaysia for studying differences in corporate governance characteristics that affect the financial disclosure, their results indicate that board ownership is associated with lower levels of corporate voluntary disclosures. A negative relationship between board ownership and corporate voluntary disclosure is, however, weaker for firms with higher proportion of INED on the AC indicating that INED moderate board ownership/corporate voluntary disclosure relationship.

Chau and Gray (2010) examine the relationship between the extent of voluntary disclosure and the level of family and board independent including the influence of an independent chairman using hand collected data on voluntary disclosure, for a sample of 273 listed firms 
in Hong Kong for the year 2002, the results show that at moderate to low levels of family share holding ( $25 \%$ or less ) the converge of interest effect is dominant and the extent of voluntary disclosure is relatively low at high levels of family shareholding. The entrenchment effect dominates and is associated with higher voluntary disclosure. In addition, the results show that the appointment of an independent chairman is positively associated the level of voluntary disclosure. Most importantly, the appointment of an independent chairman appears to mitigate the influence of family ownership on voluntary disclosure and hold for firms with a non independent chairman, while the extent to which independent non executive directors are appointed to the board is positively associated with voluntary disclosure, the role of such directors is mitigated by the role of chairman (Chau \& Gray, 2010).

Al Shammari and Al Sultan (2010) investigate the relationship between corporate governance characteristics and corporate voluntary disclosure in the annual reports of 170 Kuwaiti companies listed on the Kuwait Stock Exchange in 2007. They first identify four major corporate governance characteristics: proportion of non-executive directors to total number of directors on the board; proportion of family members to total number of directors on the board; role duality; and a voluntary audit committee. Using a self-disclosure index to measure corporate voluntary disclosure, the results indicate that only the existence of a voluntary audit committee is significantly and positively related to the extent of corporate voluntary disclosure. Al akra ET al. (2010) investigate the influence of corporate accounting disclosure regulations, governance reforms and ownership changes, resulting from privatization, on corporate mandatory disclosure compliance of Jordanian listed companies. Their results show that corporate mandatory disclosure compliance has significantly increased through the time period of the study. They run two cross-sectional regression models for 1996 and 2004. In 1996, long-term leverage and leverage appeared to be the significant variables to influence the corporate disclosure compliance of Jordanian firms. In the 2004 cross-sectional model, auditor type, the presence of the audit committee, size of the board, liquidity and gearing ratio emerged as significant determinants of corporate mandatory disclosure. However, Ownership structure and the percentage of non-executive directors on the board were insignificant in influencing disclosure. Finally, two company attributes appeared to influence corporate disclosure compliance in Jordan market capitalization and long-term leverage (Al akra et al., 2010).

Mohamed and Sulong (2010) examine the relationship between corporate governance mechanisms and extent of corporate disclosure for listed companies in Malaysia. Their results indicate the conjecture that companies with higher percentage of family members sit on the board are significantly have lower level of disclosure in their annual reports. Samah and Dahawy (2010) examine the factors influencing corporate disclosure transparency as measured by the level of corporate voluntary disclosure in the annual report of the active share trading firms in Egyptian Stock Exchange (ESE). They use archival data to collect information on the dependent variable (corporate voluntary disclosure) and independent variables (corporate governance characteristics and company characteristics). A transformed OLS regression model was used to test the association between dependent and independent variables. The study results indicate that lower managerial ownership was associated with increased in corporate voluntary disclosure; moreover there is a relationship between 
independent board of directors' existence of audit committee and corporate voluntarily disclosure.

Collett and Dedman (2010) examine the link between firm-level large share price movements, firm-specific company announcements and corporate governance. They measure corporate disclosure by identifying the largest abnormal daily stock returns for sample firms, and then firm-specific announcements in the three-day window centered on the abnormal return day are searched. Corporate governance variables known to influence corporate disclosure practice are then collected and tested to ascertain whether they influence corporate disclosure for positive and negative (good and bad announcements) abnormal returns. They find large share price movements are accompanied by an official share price movement in 45.2 per cent of cases. This rises to 62.9 per cent when new analyst or newspaper articles are included as potential drivers of the abnormal share price return. The higher proportion of non-executive directors and $\mathrm{CEO} /$ chair duality lead to a higher incidence of bad news disclosure, suggesting increased scrutiny works. The higher level of CEO and board ownership related to lower the level of disclosure. Finally, institutional ownership concentration appears to negatively influence the level of disclosure (Collett \& Dedman, 2010).

Li (2010) examines how firms' corporate voluntary disclosure decisions are influenced by product market competition. Using separate measures to capture different dimensions of competition, he shows that competition from potential entrants increases disclosure quantity, while competition from existing rivals decreases disclosure quantity. He also finds that competition enhances disclosure quality mainly through reducing the optimism in profit forecasts and reducing the pessimism in investment forecasts. Moreover, he shows that the above association is less pronounced for industry leaders, consistent with industry leaders facing less competitive pressures than industry followers. Craighead et al. (2010) find that absence of mandated disclosure, CEO cash compensation in widely held firms is less performance-contingent than in closely held firms. With the imposition of mandated disclosure, performance-contingent cash compensation increases more in widely held firms than in closely held firms.

\subsection{Studies in 2011}

Allegrini and Greco (2011) find board size and diligence have a positive relationship with corporate voluntary disclosure. The audit committee meeting frequency shows a positive impact on the amount of information corporate voluntary disclosed. They also find that the COE duality has a negative impact on corporate voluntary disclosure. Rouf and Al Harum (2011) examine the association between ownership structure and corporate voluntary disclosure levels in the 2007 annual report of 94 samples of Bangladeshi listed Companies. Ownership structure is provided by management ownership and institutional Ownership, Using unweighted relative disclosure index for measuring corporate voluntary disclosure. The extent of corporate voluntary disclosure level is measured using 68 items recommended by those who have professional qualifications. The results show that the extent of corporate voluntary disclosures is negatively associated with a higher management of ownership structure and the extent of corporate voluntary disclosures is positively associated with a higher Institutional ownership structure. 
Uyar (2011) investigates the association between firm characteristics and the corporate voluntary disclosure level of graphs in annual reports of Turkish companies listed on the Istanbul Stock Exchange (ISE). The firm characteristics that are used in the study include auditor size, ownership structure, firm performance (profitability) and firm size. By using a content analysis of annual reports of the companies listed on the ISE-100 Index for the year 2006. The results of univariate and multivariate analyses indicate that firm size, auditor size have significant positive association with corporate voluntary disclosure level of graphs. On the other hand, profitability and ownership structure do not have any significant association with graphical disclosure level.

\subsection{Studies in 2012}

Matocsy et al. (2012) examine the association between corporate mandatory disclosure and board independence based on a sample of 450 firms for the period 2006-2007 using OLS regression and two stage square regressions. They find that there is no relationship between board independence and corporate mandatory disclosure. Gao and Kling (2012) improve that auditor opinion increase the mandatory disclosure requirement, moreover internal governance measured by board size, CEO salary, CEO duality and external governance (the degree of institutional development) has a positive effect on firm compliance to corporate mandatory disclosure requirement.

Samah et al. (2012) assess the extent of corporate voluntary disclosure on the extent of corporate governance by using a measure of disclosure based on published data created from a checklist developed by the united nation, which was gathered from a manual review of financial statement and websites of a sample of ESE. The study finds that although the level of corporate disclosure is minimal disclosure, it is high for items that are mandatory under the Egyptian accounting standards. The failure of companies to disclose such information clearly shows some ineffectiveness and inadequacy in the regulatory framework in Egypt. Moreover, the phenomenon of non compliance also is attributed to socio-economic factors in Egypt. Therefore, it is expected that Egyptian firm will take a long time to appraise the pay back of increased corporate voluntary disclosure. The study findings indicate that the extent of corporate voluntary disclosure is lower for companies with duality in position and higher ownership concentrated as measured by block holders (Samah et al., 2012).

Francis et al. (2012) investigate interrelationship between corporate governance and corporate disclosure of companies on the Ghana Stock Exchange (GSE). Using a random effect panel regression analysis to establish the relationship between corporate disclosure and corporate governance of 20 listed companies covering a period from 2003-2007. The results indicate that although there has been improvement of disclosure practices over the years, the level of disclosure in Ghana is moderate/fair. The study also documents a significant positive relationship between the presence of accounting/finance expert(s) on the audit committees and corporate disclosure practices. Qu et al. (2012) examine the corporate voluntary disclosure made by 297 Chinese listed firms in their 1995-2006 annual reports. They determine how firms in the Chinese stock market have responded to the coercive pressure exerted upon them by the market regulatory body, the Chinese Security Regulatory Commission (CSRC) in terms of providing transparent information to the stock market. They 
find that over the study period, listed companies have gradually increased their voluntary disclosure. The study also explores the main characteristics of corporate voluntary disclosure made by listed firms in the Chinese stock market. They conclude that corporate voluntary disclosure has been adopted by firms to achieve institutional legitimacy in the stock market.

Chakbourn and Matoussi (2012) analyze the interactions between the external and internal mechanisms of corporate governance and corporate voluntary disclosure in the annual reports in the Tunisian emerging market. They investigate the association between the regulatory reform competition on the market of goods and services, ownership structure, composition of the board of directors and the extents of corporate voluntary disclosure in the annual reports. They conduct their statistical analysis on a sample of Tunisian listed companies of the non-financial sector of 144 observations firm-years during the period 2003-2008. The results provide a strong support that index of corporate voluntary disclosure is affected by the external and internal mechanisms of governance, specifically, governance mechanisms that sometimes represent substitutes and sometimes complements corporate voluntary disclosure extents. Nevertheless, they find that there is an impact of the institutional and managerial ownership on the extent of the voluntary disclosure.

Utama (2012) claims that companies with medium level of block holders have a lower disclosure level. However, companies with high levels of ownership have a high level disclosure. Alves et al. (2012) examine the determinants of corporate voluntary disclosure, and its different categories, in the annual reports of Portuguese and Spanish listed companies. They investigate the association among corporate characteristics, corporate governance variables and corporate voluntary disclosure. By building a corporate voluntary disclosure index based on the information companies provided in their annual reports. The results indicate that the main determinants of corporate voluntary disclosure are these variables related to firm size, growth opportunities, organizational performance, board compensation and the presence of a large shareholder.

\subsection{Studies in 2013}

Hassan (2013) investigates the introduction of a corporate governance code in 2005 on the levels of compliance with mandatory International Financial Reporting Standards (IFRS) disclosure requirements by companies listed on ESE as a leading stock exchange in the Middle East, by using a disclosure index derived from mandatory IFRS disclosure requirements for the fiscal year. The study use board characteristics and ownership structure as corporate governance mechanisms. The results show that there is no relation between corporate governance and corporate mandatory disclosure in Egypt. Hasan et al. (2013) examine the level of financial disclosures among Bangladeshi companies and its association with corporate governance characteristics. They conclude that the level of financial disclosures in Bangladesh has been increasing gradually but it is still below the level of expectation. In addition, the reliability and transparency level of financial disclosures is very low and hence the confidence level of external users' is also very low. Therefore, shareholders do not use the information provided in the annual report to make their economic decisions. Using six corporate governance variables, the association between external auditor and the level of financial disclosures is found significantly. 
Hajji and Ghazali (2013) investigate the quality of corporate voluntary disclosure practices by Shariah compliant companies (ShCCs) in Malaysia. They also examine factors influencing the quality of corporate voluntary disclosures. Using weighted disclosure analyses approach, a self-constructed disclosure checklist was developed to measure the quality of corporate voluntary disclosures (CVDs). They examine the annual reports of a sample of 76 ShCCs selected from various sectors listed on Bursa Malaysia in the year 2009. They indicate that the quality of voluntary disclosures by ShCCs is in overall low consistent with prior studies that gauged the quality of CVDs in Malaysia. The multivariate regression analyses reveal that board size is significant in explaining the quality of CVDs at the 5 per cent significance levels. Company size and leverage as control variables are also significant at the 1 and 10 per cent significance levels in determining the quality of CVDs by ShCCs. The reduced regression model further indicates that government ownership is highly significant at the 1 per cent significance level in explaining the quality of CVD by ShCCs while leverage is significant at the 5 per cent levels (Hajji \& Ghazali, 2013).

\section{Conclusion and suggestions}

\subsection{Audit committee characteristics}

Prior studies examine the relationship between corporate voluntary disclosure and audit committee characteristics. However, more research needed to test the relationship between audit committee characteristics and corporate mandatory disclosure. Researchers also can investigate other factors effect this relationship such as country economics, industry type, and company size. Regulators have only recently begun to recognize the importance of the internal audit function (IAF) for external financial reporting; the IAF has long been recognized in the academic literature as part of corporate governance, with a critical monitoring role (Anderson et al., 1993), and models of corporate governance have long included the IAF (Skousen et al. 2005; Hermanson \& Rittenberg, 2003). Cohen et al. (2004) provide a theoretical framework for the corporate governance mosaic and its impact on financial reporting quality, and the IAF appears as one of the main stakeholders that play a significant role in monitoring financial reporting quality. Similarly, the Institute of Internal Auditors (IIA) model of corporate governance suggests that the IAF is one of four cornerstones of high quality corporate governance, together with management, an audit committee and external audit. Therefore, the governance process impacts the quality of financial reporting (Cohen et al., 2004). The IAF often has the primary responsibility for day-to-day monitoring of management actions (Gil et al., 2012, p.731). So I think that the relationship between internal audit quality and both corporate mandatory disclosure and corporate voluntary disclosure needs more investigation.

\subsection{Board gender}

$\mathrm{Wu}$ (2010) find that the market reacts less negatively to the negative earnings announcements when companies are under the control of female CFOs than when companies are under the control of male CFOs. He finds that after companies change their CFOs from male to female, firms' analysts' forecast bias, stock return volatility and cost of bank loans are also reduced. Therefore, more investigation is required to test the association between voluntary/mandatory 
disclosure and company board gender.

\subsection{Board of directors}

There is mixed results related to the relationship between independent board of directors and corporate disclosure. For example, Chau and Gray (2010), Samah and Dahawy (2010) find a positive relationship between independent board of directors and corporate disclosure. Meanwhile, Al Shammari and Al Sultan (2010) find no relationship between board independence board of directors and corporate voluntary disclosure that lead us to investigate the impact of culture and socio economic on the relationship between independent board of directors and disclosure using different kind of disclosure measure.

\subsection{Board size}

Hasan et al. (2013) find no relationship between board size and corporate disclosure. Other find a positive relationship so future research on board size and disclosure using different type of disclosure measure. Matsunaga and Yeung (2008, pp. 5-6) view that CEOs without formal experience either have a sufficient level of financial expertise to determine effective financial disclosure policies or delegate financial disclosure decisions to the CFO, they observe differences across CEOs with regard to their financial experience. Given the highly technical and specialized knowledge associated with financial reporting decisions and the financial reporting environment, they suggest that CEOs will differ with respect to their financial expertise and that their experience in dealing with financial market participants should influence their financial disclosure policies (Matsunaga \& Yeung, 2008). Future research can investigate the relationship between CEO expertise using different type of disclosure' measure.

\subsection{External auditors}

External auditors play a valuable role in the governance of firms. The necessity for an independent external audit of the financial statements is widely acknowledged and provides reassurance to investors of managers' stewardship of the firm's resources (Watts \& Zimmerman, 1983). Firms with boards that are more independent may pay higher audit fees, suggesting independent directors demand greater diligence on the part of the auditor (Carcello et al., 2002).

\subsection{Audit quality}

Audit quality is itself not directly observable so proxies are used for it, such as the size of the audit firm. Large audit firms have a more valuable reputation to protect and are a bigger target for litigation (DeAngelo, 1981; Dye, 1993), which provides them with an incentive to be more conservative and more diligent, hence the historical association of higher audit quality with larger audit firms (DeAngelo, 1981; Palmrose, 1988; Lennox, 1999a). Large audit firms have more resources available to them and their 'deeper pockets' (Lennox, 1999b) may also contribute to their greater litigation risk. For these reasons, clients may have believed larger audit firms offer greater assurance on financial statements prepared for external parties and consequently they may have appointed a larger audit firm to signal their own quality (Philip et al., 2010, pp.115-116). It is also assumed that these firms have a 
greater incentive to protect their reputation because of their larger client base (Francis et al., 1999; Francis and Krishnan, 1999; Kim et al. 2003; Krishnan, 2003). Clarkson et al. (2003) found strong support for an association between the level of disclosure and the use of a Big Six audit firm. So, future research can investigate the impact auditor skill and quality on disclosure using different type.

\subsection{Regulatory bodies}

The political cost theories states that the firm sensitive regulation, nationalization, expropriation are more likely to reveal information in order to decrease related costs companies usually attempt to keep corporate wealth from being shift toward the public sector (Álvarez et al., 2008). Previous studies examine the relationship between corporate disclosure and regulatory bodies (as external governance mechanism (Al akra et al., 2010, Apostolos \& Nanopoulos, 2009; Qu et al., 2012). However, future research can investigate the relationship between corporate disclosure (voluntary disclosure and regulatory bodies such as government regulation, labor union, securities and exchange market, industry regulation using a different type of disclosure measure.

\subsection{Market product and competition}

Although, some study examine the relationship between market product, competition and corporate disclosure ( $\mathrm{Li}$ et al., 2010), future research can examine this relationship in different countries using different method to measure disclosure. Future research can also examine the impact of mandatorylvoluntary disclosure on CEO cash compensation $\backslash C E O$ hiring and turnover.

\section{References}

Akhtaruddin, H., Hossain, M.A., \& Yao, L. (2009). Corporate governance and voluntary disclosure in corporate annual reports of Malaysian listed firms. Journal of Applied Management Accounting Research, 7(1), 1-20.

Al akra, Eddie, \& Ali, M. (2010). The influence of introduction accounting disclosure regulatory on mandatory disclosure compliance, evidence from Jordan. The British Accounting Review, 42(3), 170-186.

Al Shammari, B., \& Al sultan, W. (2010). Corporate governance and voluntary disclosure in Kuwait. International Journal of Disclosure and Governance, 7, 262-280.

Allegrini, M., \& Greco, G. (2011). Corporate boards, audit committees and voluntary disclosure: evidence from Italian Listed Companies. Journal of Management and Governance, [Online] Available: http://www.springerlink.com/content/32720028107w4746/fulltext.pdf (March 15, 2013).

Álvarez, A. G., García-Sánchez, A. M., \& Dominguez, L. R. (2008). Voluntary and compulsory information disclosed online: The effect of industry concentration and other explanatory factors. Online Information Review, 32(5), 596-622.

Alves, H., Rodrigues, A. M., \& Canadas, N. (2012). Factors influencing the different categories of voluntary disclosure in annual reports, an analysis of Iberian Peninsula listed 
companies. Tekhne, 10(1), 15-26.

Apostolos, K. A., \& Nanopoulos, K. A. (2009). Voluntary accounting disclosure and corporate governance: evidence from Greek listed firm. International Journal of Accounting and Finance, 1(4), 395-414.

Barako, D. G., Hancock, P., \& Izan, H. Y. (2006). Factors influencing voluntary corporate disclosure by Kenyan companies. Corporate Governance: An International Review, 14(2), 107-125.

Barako, D. G. (2007). Determinants of voluntary disclosure in Kenya companies annual reports. African Journal of Business Management, 1(5), 113-128.

Bokpin, G. A., \& Isshaq, Z. (2009). Corporate governance, disclosure and foreign share ownership on the Ghana stock exchange. Managerial Auditing Journal, 24(7), 688-703.

Brown, P., Beekes, W., \& Verhoeven, P. (2010). Corporate governance, accounting and finance, a review. Accounting and Finance, 51 (1), 96-172.

Cheng, C. M., \& Courtenay, S. M. (2006). Board composition, regulatory regime and voluntary disclosure. The International Journal of Accounting, 41(3), 262-289.

Chen, S., Chen, X., \& Cheng, C. M. (2008). Do family firms provide more or less voluntarily disclosure? Journal of Accounting Research, 46 (3), 499-536.

Chau, G., \& Gary, S. J. (2010). Family ownership, board independence and voluntary disclosure. Journal of International Accounting, Auditing and Taxation, 19(2), 93-109.

Collett, N., \& Dedman, E. (2010). Large share price movements, the disclosure of news and corporate governance, implication for disclosure rules. Journal of Applied Accounting Research, 11(2), 109-132.

Craighead, J. A., Margnan, M. L., \& Throne, L. (2010). The impact of mandated disclosure on performance based CEO compensation. Contemporary Accounting Research, 21(2), 346-398.

Chakroun, M. (2012). Determinants of the extent of voluntary disclosure in the annual reports of the Tunisian firms. Accounting and Management Information System, 11(3), 335-370.

Donnelly, R., \& Mulcahy, L. (2008). Board structure, ownership and voluntary disclosure in Ireland. Corporate Governance: An International Review, 16(5), 416-429.

Eng, L. L., \& Mark, Y. T. (2003). Corporate Governance and voluntary disclosure. Journal of Accounting and Public Policy, 22(4), 325-345.

Aboagye-Otchere, F., Bedi, E., \& Kwakpe, T. O. (2012). Corporate governance and disclosure practice of Ghanaian listed companies. Journal of Accounting in Emerging Economies, 2(2), 140-161.

Gao, L., \& Kling, G. (2012). The impact of corporate governance and external audit on compliance to mandatory disclosure requirement in china. Journal of International Accounting, Auditing and Taxation, 2 (1), 17-31. 


\section{MInstitute Macrothink $_{\text {Int }}$}

Journal of Public Administration and Governance ISSN 2161-7104

Garcia-Meca, E., \& Sanchez-Ballesta, J. (2010). The association of board independence and ownership concentration with voluntary disclosure. European Accounting Review, 19(3), 125-146.

Gil, E. G., Hernandez, S. M., \& De Lema, D. G. (2012). Internal audit and financial reporting in the Spanish banking industry. Managerial Auditing Journal, 27(8), 728-753.

Haniffa, R. M., \& Cook, T. E. (2002). Culture, corporate governance and disclosure in Malaysian corporate, Abacus, 38(3), 317-349.

Haron, M., and Akhtaruddin, H. (2010). Board ownership, audit committee effectiveness and corporate voluntary disclosure. Asian Review of Accounting, 18(3), 245-259.

Hasan, S., Hossain, S. Z., \& Swieringa, R. J. (2013). Corporate governance and financial disclosure in Bangladesh perspective. Research Journal of Finance and Accounting, 4(1), 109-119.

Hassan, M. (2013). The introduction of corporate governance codes in a transitional economy and its impact on compliance with mandatory disclosure - the case of Egypt. International Journal of Research in Business and Social Science, 2(1), 7-21.

Hajji, G. (2013). The quality and determinants of voluntary disclosure in annual reports of Shariah compliant companies in Malaysia. Humanomics, 29(1), 24-42.

Ho, Wong. (2001). A study of the relationship between corporate governance structure and the extent of voluntary disclosure. Journal of International Accounting, Auditing, Taxation, 10(2), 139-156.

Huafang, X., \& Jiangua, Y. (2007). Ownership structure, board composition and corporate voluntary disclosure, evidence from listed companies in china. Managerial Auditing Journal, 22(6), 604-619.

Kent, P., \& Stewart, J. (2008). Corporate governance and disclosure on the transition to international financial reporting standards. Accounting and Finance, 48(4), 649-671.

Khlif, H., \& Souissi, M. (2010). The determinants of corporate disclosure - a Meta analysis. International Journal of Accounting and Information Management, 18(3), 198-219.

Lim, S., Matolcsy, Z., \& Chow, D. (2007). The association between board composition and different type of voluntary disclosure. European Accounting Review, 16(3), 555-583.

Li, H., \& Qi, A. (2008). Impact of corporate governance on voluntary disclosure in Chinese listed companies. Corporate Ownership and Control, 5(2), 360-366

Laidroo, L. (2009). Association between ownership structure and public announcements' disclosure. Corporate Governance: An International Review, 17(1), 13-34.

$\mathrm{Li}, \mathrm{X}$. (2010). The impact of product market competition on the quantity and quality of voluntary disclosure. Review of Accounting Studies, 15(3), 663-711.

Mohamed, W., \& Sulong, Z. (2010). Corporate governance mechanisms and extent of disclosure, evidence from listed companies. International Business Research, 3(4), 216-228. 


\section{Macrothink}

Journal of Public Administration and Governance

ISSN 2161-7104

2013, Vol. 3, No. 3

Matocsy, Z., Tyler, J., \& Wells, P. (2012). Is continuous disclosures associated with board independence? Australian Journal of Management, 37(1), 99-124.

Qu, W., Cooper, B. J., Wise, V., \& Leung, P. (2012). Voluntary disclosure in a changing regulatory environment, evidence from Chinese stock market. International Journal of Economics and Finance, 4(4), 30-43.

Rouf, M. A., \& Al Harum, M. A. (2011). Ownership structure and voluntary disclosure in annual reports of Bangladesh. Pak. J. Commer. Soc. Sci, 5 (1), 129-139.

Samah, K., \& Dahawy, K. (2010). Factors influencing corporate disclosure transparency in the active share trading firm, an explanatory study. Research in Accounting in Emerging Economies. (10), 87-112.

Samaha, K., Dahawy, K., Hussainey, K., \& Stapleton, P. (2012). The extent of corporate governance disclosure and its determinants in a developing market, the case of Egypt. Advance in International Accounting, 28(1), 168-178.

Tsamenyi, M., Enninful-Adu, E., \& Onumah, J. (2007). Disclosure and corporate governance in developing countries: evidence from Ghana. Managerial Auditing Journal, 22(3), 319-334.

Uyar, A. (2011). Firm characteristics and voluntary disclosure of graphs in annual reports of Turkish listed companies. African Journal of Business Management, 5(17), 7651-7657.

Utama, C. A. (2012). Company disclosure in Indonesia, corporate governance practice, ownership structure, competition and total assets. Asian Journal of Business and Accounting, 5(1).75-108.

Wu. Z. (2010). Three essays on corporate governance and financial disclosure, Unpublished $\mathrm{PhD}$ thesis. [Online] Available: www.proquest.com (February 9, 2013).

Yifang, W. (2009). Corporate governance, disclosure method and information asymmetry, Unpolished Master thesis, Edward school of business, Canada. [Online] Available: www.proquest.com, last review (February 10, 2013).

\section{Copyright Disclaimer}

Copyright reserved by the author(s).

This article is an open-access article distributed under the terms and conditions of the Creative Commons Attribution license (http://creativecommons.org/licenses/by/3.0/). 